\title{
THE STANDARD OF RESEARCH ON THE BATTLE OF CUITO CUANAVALE, 1987-1988
}

\author{
Leopold Scholtz ${ }^{1}$ \\ Department of History, Stellenbosch University
}

\begin{abstract}
The purpose of this article is to examine the standard of research about the so-called Battle of Cuito Cuanavale. After examining what objectivity for the academic researcher should mean, two categories of researchers are looked at. The first is called the "non-researchers". They are those who do no or virtually no real research into the events at Cuito Cuanavale, but uncritically copy what politicians and politically correct academics have to say about the subject. The focus also falls on one particular historian, Italian-American Professor Piero Gleijeses. On the basis of several articles (his book about Cuba's role in Africa until 1976 is judged to be good), the conclusion is that his evident admiration for Cuba and its dictator, President Fidel Castro, and his revulsion at apartheid South Africa brings about a one-sided and distorted picture of what went on at Cuito Cuanavale and the Border War in general. The last category is the "serious researchers", whose work is based on good research. Although their work displays certain gaps in the sense that they had no access to Cuban or Angolan sources, they generally are much more reliable in their facts than the "non-researchers" and Professor Gleijeses.
\end{abstract}

\section{Introduction}

The so-called Battle of Cuito Cuanavale (August 1997-July 1988) was the culmination of the Border War. As such, this battle has become the focal point of the public debate about the question who actually won the war.

Scientia Militaria, South African Journal of Military Studies, Vol 39, $\mathrm{Nr} 1,2011$, pp. 115-137. doi: $10.5787 / 39-1-105$
I have written several articles about the war, concluding - on the basis of, inter alia, archival research - that in the end it was a draw, allowing both South Africa and Cuba to withdraw from the war with honour, while the 
Angolan MPLA government lost badly. ${ }^{2}$ There is no need to go into that again. However, while working on those articles, it struck me forcefully how low the standard of research in some academic quarters was on the events at Cuito Cuanavale and the Border War in general. Those quarters happen to be especially those who hold the view that the South African Defence Force (SADF) was badly beaten and that, as a result, South Africa had to sue for peace and was driven out of Namibia. I am expressly not including politicians here, a species which is in general (there are, of course, notable exceptions) well known for its incapability to adhere to the truth. However, for proper researchers, be they historians, political scientists or sociologists (even journalists!), more stringent yardsticks apply.

The purpose of this article is, therefore, to examine the standards of the research on the Battle of Cuito Cuanavale.

\section{Historical writing}

What can in fairness be expected of a historian? And what should not be expected?

Perhaps the most difficult characteristic for anyone venturing in the minefield that is historical writing, is objectivity. Of course, total objectivity is impossible for any human being. Present-day historians have long since evolved beyond the axiom coined by Leopold von Ranke, father of modern historical writing, that its purpose should be limited to reconstruct the past - bloss zeigen, wie es eigentlich gewesen war ("simply show how it actually was"). ${ }^{3}$ To begin with, the answers given by historians will evolve through time because the questions they put to the sources change. Put differently, as Arthur Marwick has it, "each age writes its own history, for each age will make a different evaluation of what is 'significant' in its own past, will tend to see the past in the light of its own preoccupations and prejudices".

Secondly, the historian does not, like the scientist with his experiment in the laboratory, stand entirely separately and independently from his work. He selects facts and viewpoints, at least partially (and perhaps unconsciously) influenced by his worldview and the world around him. In other words, the "facts" presented by him in the end, are influenced by his mind and approach. At the same time, the historian's perception is also influenced by all the facts he has marshalled. "The relation between the historian and his facts is one of equality, of give-and-take," E.H. Carr writes. "As any working historian knows, if he stops to reflect what he is doing as he thinks and writes, the historian is engaged on a continuous process of moulding his facts to his interpretation and his interpretation to his facts." Because 
"[t]he historian without his facts is rootless and futile" and "the facts without their historian are dead and meaningless", history is "a continuous process of interaction between the historian and his facts, an unending dialogue between the present and the past". 5

In the third place, no researcher goes through life as a blank page. Everybody has some beliefs - religious, social, economic, political and so on. Human life would be impossible without them. The Dutch historian Ger Groot makes the point that the historian, like other people, has certain "general insights", which he gets, consciously or unconsciously, "from the culture in which he grew up and which moulded him". The trick is to know this and to counter it as far as possible. $^{6}$

From this flows the simple conclusion that independent-minded researchers who value their academic integrity will never totally agree on anything. This is not only natural; it is good. Only through open debate, placing viewpoint next to viewpoint on the market place of ideas, can humanity progress.

Finally, the question is how far a historian may let himself be led by his personal beliefs. G.D. Scholtz writes that, although total objectivity is impossible, the question may be asked whether the historian should let his love or hate for a certain matter be decisive in his work. The answer is "no," he argues, and continues, "'n Historikus wat die prooi van sy eie subjektiewe gevoelens is wanneer hy die pen opneem, is geen ware historikus in die ware sin van die woord nie ... Juis een van die vernaamste toetse vir die grootheid van 'n historikus is die wyse waarop hy bereid is om 'n waarheid wat miskien vir sy eie gevoelens en opvattings onaangenaam mag wees, na vore te bring en dit in die regte perspektief te stel."7 This, of course, also implies that a historian's research must be comprehensive. One cannot shun some sources because they could clash with your favoured interpretation. Too much bias inevitably leads to incompleteness.

In the same vein, the renowned French historian Marc Bloch writes,

There are two ways of being impartial: that of the scholar and that of the judge. They have a common root in their honest submission to the truth. ... However, there comes a moment when their paths divide. When the scholar has observed and explained, his task is finished. It yet remains for the judge to pass sentence.

He then applies this metaphor:

Now, for a long time, the historian has passed for a sort of judge in Hades, charged with meting out praise or blame to dead heroes. ... 
The words of Pascal are more to the point than ever: 'We all play God in judging: this is good or this is evil.'

However, he adds,

Are we so sure of ourselves and our age as to divide the company of our forefathers into the just and the damned? How absurd it is, by elevating the entirely relative criteria of one individual, one party, or one generation [sic!] to the absolute, to inflict standards upon the way in which Sulla governed Rome, or Richelieu the States of the Most Christian King! Moreover, since nothing is more variable than such judgements, subject to all the fluctuations of collective opinion or personal caprice, history, by all too frequently preferring the compilation of honor rolls to that of notebooks, has gratuitously given itself the appearance of the most uncertain of disciplines ...

If the judgement only followed the explanation, the reader could simply skip it. Unfortunately, the habit of passing judgements leads to a loss of taste of explanations. When the passions of the past blend with the prejudices of the present, human reality is reduced to a picture in black and white. ... When all is said and done, a single word, 'understanding', is the beacon light of our studies. ${ }^{8}$

Against this background, one may come to some general conclusions regarding the task of the historian. Above all, he or she must analyse, explain and understand (which is, of course, not the same as condoning). Dishing out moral judgements may give a certain emotional satisfaction to the historian concerned, but all too often stands in the way of proper analysis, explanation and understanding. It is perfectly natural and legitimate to have political and other beliefs. However, somewhere the line must be drawn. One cannot become guilty of what the Germans call hineininterpretieren - basically, reaching conclusions before researching properly and then seeking facts and quotes to support such conclusions.

Above all, and this may sound childishly self-evident, you have to do at least some research. One cannot simply follow politicians' one-sided truths or other academics' politically correct utterances and then present this as being proper research. As we shall see presently, this is exactly what some historians actually do.

In the following review, I have to stress that I do not care what researchers' political persuasions are. Academic standards are the only thing that counts. 


\section{The 'non-researchers'}

To start somewhere, perhaps randomly: Canadian political scientist Isaac Saney, who calls the Battle of Cuito Cuanavale "South Africa's Stalingrad", says the SADF "went to great lengths to deny what actually happened at Cuito Cuanavale". According to him, one of the South African objectives was -

...to capture Menogue [sic], the capital of Cuando Cubango Province, and thus establish a quasi-state in southern Angola that would be under the control of UNITA. This was to be the prelude to the subjugation of Angola and the installation of a Luanda government under South African tutelage.

Saney, therefore, states that the South Africans "were determined to capture the town and strategic military base of Cuito Cuanavale", in order to cement "Pretoria's control over the southern African region". However, this dastardly plan was thwarted by the heroic intervention of Cuba's President Fidel Castro. ${ }^{9}$

Saney's cites two sources for this view. The first is an article by one Horace Campbell, ${ }^{10}$ a Jamaican academic. However, upon reading Campbell's article its becomes clear that it has no academic value at all, as there are no footnotes or source list, and the article is full of unsubstantiated allegations and opinions. Saney's other source is a publication of the "Ex-Combatants Association of South Africa", which describes itself as "a group of ex MK/ANC members"11 - hardly an authoritative or objective source when analysing the motives and objectives of the South African government and the SADF behinds the scenes in 1987-'88. (A little earlier, Saney also authored a book about the Cuban Marxist-Leninist political system, which, according to his analysis, was far superior to Western liberal multi-party democracy. ${ }^{12}$ This makes his viewpoint about Cuito Cuanavale perhaps more understandable.)

Just to return to Campbell's worth as a source for a moment: He claims that "Operation Modular Hooper" [sic] was launched "to seize Menongue and set up a provisional UNITA government". But, in the course of the campaign,

... the South African army, supposedly the best on the continent, was trapped with its tanks and artillery [sic] and held down more than 300 miles from its bases in Namibia [sic]. Failing to take Cuito Cuanavale with over 9000 soldiers [sic], even after announcing that it had done so [sic], losing air superiority [sic], and faced with mutinies among black troops [sic] and a high casualty rate among whites [sic], the South Africans reached such a desperate situation 
that President Botha had to fly to the war zone when the operational command of the SADF broke down [sic]. ${ }^{13}$

Just about the only truth in this paragraph is that the South Africans were engaged in a war in Angola. Campbell either has not the foggiest idea of what really went on, or he is deliberately spouting propaganda. In fact, South Africa never thought that it would be able to replace the MPLA as government with UNITA, the SADF never was "trapped", it never announced the capture of Cuito Cuanavale, there were never more than 3000 South African troops engaged in this operation, losing air superiority did not affect the SADF operation decisively, ${ }^{14}$ the story about "mutinies among black troops" is highly exaggerated, there was no "high casualty rate among whites", and President PW Botha's visit to the front had a totally different context. ${ }^{15}$ And yet Saney deems him a trustworthy source!

Another example is Professor Gary Baines, historian at the Rhodes University in Grahamstown. As far as one can make out from his writings, Baines has done very little research into the Border War itself. His field of expertise appears to be the way in which South African society struggles to come to terms with the legacy of the war - in itself a very legitimate field of study. I am deliberately not expressing myself on his main study field, about which I do not consider myself competent enough.

Nevertheless, without any meaningful research about the war as such, Baines uncritically adopts the Cuban version of the facts. He writes that the "Cuban challenge to the SADF's air superiority broke the deadlock on the battlefield in southern Angola and forced the SADF troops to beat a hasty retreat to the Namibian border". No sources are cited. He talks of "the needless war waged in the name of apartheid and anti-communism by the apartheid state" ${ }^{16}$ thereby clearly nailing his ideological colours to the mast. This, of course, is his right. However, bad workmanship is not.

Elsewhere, Baines writes, "troops were not briefed beforehand that they were bound for Angola, and officers were instructed not to divulge the enemy's logistical and numerical superiority to their own troops at the battle of Cuito Cuanavale" ${ }^{17}$ Note that Baines makes a general statement, the implication being that South African troops were never or perhaps seldom told that they were going to Angola. What are his sources for this sweeping statement? One is Clive Holt's book $^{18}$ about his experiences as a member of 61 Mechanised Battalion Group during Operation Hooper near Cuito Cuanavale in 1988, pages 122 and 137. The other is a novel by Mark Behr, The Smell of Apples. ${ }^{19}$ 
Let us examine this. Clive Holt does indeed write that he and his fellow soldiers were not told that they were going to be part of Operation Hooper. May one extrapolate from this single source the implication that this was a general policy? One would think not. Moreover, Holt never says that officers were forbidden to divulge "the enemy's logistical and numerical superiority". That information comes from Behr's novel, which is a quite novel way of writing history. It may be that Behr's book contains some autobiographical material. But how to separate his fact from fiction? What happened to the academic principle that research must be verifiable?

In another paper about Holt's book, Baines talks about "a decisive setback in the SADF's bid to capture Cuito Cuanavale". The SADF generals' claim that they never intended to occupy the town is summarily rejected as "pure spin". (His only source for this claim is a speech by Mr Ronnie Kasrils, ex-Deputy Minister of Defence in ex-President Thabo Mbeki's government, hardly a credible source for the SADF high command's inner thoughts in 1987-'88.) Bains repeats that "[i]t was the SADF whose teeth had been broken. For the first time ever the Cubans threatened the Namibian border and the SADF appeared vulnerable". He also asserts, "it was the South Africans who sued for peace and brokered the negotiations that culminated in their withdrawal from Namibia and of Cuban forces from Angola". No sources are cited. ${ }^{20}$

I have - I hope - elsewhere credibly established that the SADF was hesitantly and incrementally drawn into the cauldron, that a regime change in Luanda was not part of South Africa's objectives, and that the generals' contention that they never planned to take Cuito Cuanavale (except if it fell into their laps with very little fighting) is true. In the first phase of the campaign, they simply wanted to stop the Angolan offensive against UNITA. Then President PW Botha ordered a counteroffensive to hit the Angolans so hard that another offensive before the end of 1988 would be impossible. In operational terms, this meant that the Angolan forces either had to be destroyed east of the Cuito River or driven across it, that the river had to be prepared as a defensive position and turned over to UNITA, and that the SADF then had to pull back. ${ }^{21}$ Of course, Baines did not have access to this research, which was at the time of his writing still only a glint in my eye. However, he bases his conclusions on articles by Ronnie Kasrils, Piero Gleijeses and Edgar Dosman, none of which are very trustworthy either.

We shall examine Gleijeses' work separately, but let us in the meantime look at Canadian academic Edgar J. Dosman. Dosman writes that the SADF planned two more operations just after the Lomba battles (which took place in SeptemberOctober 1987), Hooper and Packer, "with the purpose of moving on Cuito 
Cuanavale and destroying the FAPLA brigades which had escaped the Lomba, and then moving north [sic, he probably means east - LS] to threaten the main garrison of Menongue". No sources are cited. He further claims that

[t]o the west the SADF gained approval for four 1988 operations: Hilti I and II; Excite; Fulton; and Florentum, with the overall objective of replicating the results on the Lomba River by rolling up FAPLA forces in the strategic Cunene province. Militarily these four SADF operations would complete the eviction of FAPLA from the south, but they also fit into a broader military and political strategy against Angola and Namibia. Pretoria viewed a change in regime in Angola, with UNITA replacing the MPLA, as a vital safeguard for its interests in southern Africa. ${ }^{22}$

When examining this passage, it falls flat. Dosman offers no source for the last two sentences at all, while he writes in an endnote supporting the allegation about the planned operations, "Information on the four SADF operations proposed for western Angola was derived from SADF field commanders."23

We are not told who these "SADF field commanders" were, what their ranks were, where and when they served, how they came to possess this knowledge nothing that makes it possible for the academic reader to assess the credibility of this piece of evidence. We do not know whether their words were recorded or written down or when it happened.

Furthermore, it is clear that Dosman himself makes serious factual errors in the passage quoted above. To begin with, as far as I could establish, there was only one Operation Hilti - which in any case existed only on paper. It was a contingency plan for defending Namibia in case the Cuban forces decided to invade the territory after their famous southwards march to the border. ${ }^{24}$ Operation Excite was the last SADF operation on Angolan soil in June 1988, when elements of 32 Battalion, 101 Battalion and 61 Mechanised Battalion Group crossed the border near the water works of Calueque in order to check the above-mentioned Cuban advance. This resulted in a sharp fight in which the South Africans were pushed back, and a second in which the Cubans reeled back with a bloody nose. The objective having been reached, the SADF force withdrew across the border. ${ }^{25}$ Nothing could be discovered about an Operation Fulton, if it ever existed. The nearest we come to an operation confirming Dosman's view, is Operation Florentine. According to Brigadier-General Dick Lord, this was part of Operation Assassin (the name was later changed to Prone), which was planned as a major division-sized invasion of Angola to retake 
the territory occupied by the Cubans in their southward march. It never progressed beyond its preparatory stages because the peace negotiations overtook it. $^{26}$

To offer these operations, which were all hatched deep into 1988, as "proof" of major South African plans just after the Lomba battles in September-October 1987 to subjugate Angola and replace the MPLA government with UNITA in Luanda, is simply incredible for a serious academic. If one wants to make such an assertion, more credible sources - for instance, archival records - are needed.

Another pair of writers by and large supporting the above interpretation are Cuban journalist Hedelberto López Blanch and South African political scientist Ian Liebenberg. In an article in a serious academic publication, but referring to a curious small number of sources, they echo the official Cuban view that the South Africans were utterly trounced and that this broke the back of the apartheid government. As far as Cuito Cuanavale is concerned, they acknowledge in a footnote, "[n]o talks about taking Cuito seemingly took place in security circles". On the other hand, they go on, "observers frequently argued that the idea might have been to take Cuito in the hope to establish a further platform in the area for UNITA in the longer run". They fail to tell us who these "observers" are, but instead quote a "retired SADF officer" (again, without letting on what his name or rank was) who "once commented that 'halfway things changed and people started to say that it was not the intention to take Cuito'."27 Without proper sources, this allegation is also meaningless.

\section{Piero Gleijeses}

Next we have to consider the work of Italian-American historian Piero Gleijeses, a serious academic with a fine reputation. Gleijeses' reputation in this regard is mainly based on his book about Cuba's intervention in Africa between 1962 and $1976 .^{28} \mathrm{He}$ has been writing a sequel, taking the story up to the final Cuban withdrawal in 1991, and visited South Africa in 2007 in order to conduct research. At the time of reporting on this study, it was not known whether this second book had already been completed or when it would appear. However, Gleijeses also published several academic articles in which he summarised his main conclusions. $^{29}$

Gleijeses' book was received well in historians' circles, and rightly so. Although his sympathy with Cuba and his antipathy to the US and South Africa glimmers through, it remains within academically acceptable boundaries. His main service to history is that he was the first - and thus far only - historian to be granted 
access to Cuban archives. As such, he has deepened our understanding of the dramatic events in and around Cuba and Angola in 1974-'76.

His subsequent articles, however, fall far short from the fairly business-like approach of his book. While they do bring forth a host of very valuable information, it seems as if he is on a crusade to portray Fidel Castro and Cuba in the best possible light, and the US and South Africa as utterly irredeemable villains.

To begin with, he writes that the Cuban troops' presence in Angola was "a legal act", as they "were in Angola at the invitation of the government", in contrast to "South Africa's illegal occupation of Namibia". ${ }^{30}$ However, how the MPLA came to be the government in the first place, is a question he studiously avoids. After all, did they not get to be the government because they got the better of the FNLA and UNITA in a civil war after Cuba's military intervention in 1975 (was that a "legal act"?) and Soviet aid?

He alleges that South Africa "opposed Namibian independence and sought a military solution in Angola that could propel UNITA to power". ${ }^{31}$ This is taking a shortcut. South Africa accepted the inevitability of an independent Namibia already in 1978. What it did not accept, rightly or wrongly, was the inevitability of a Communist SWAPO government in power in Windhoek, as this was viewed as against South African security interests. In addition, all primary sources point to South Africa realising that whatever it would have liked to do, it knew it did not have the necessary leverage to force a regime change in Luanda. ${ }^{32}$

Gleijeses suggests rather than alleges that the SADF had its eyes fixed on Cuito Cuanavale. He writes, "By mid-January 1988 South African military sources and Western diplomats were announcing that the fall of Cuito was 'imminent'."33 His reference for this is "front-page coverage in The Star (Johannesburg, 21 January 1988)", which is, however, hardly an authoritative source for secret government and SADF planning.

Besides, there are other news reports dating from approximately the same time, appearing in newspapers belonging to the same chain as The Star, with a contrary content. For instance, The Argus reported (also on its front page), that "informed sources said this week the irony was that neither South Africa nor the rebel movement Unita want to occupy it [Cuito]". Further on the report states, "The sources said it was wrong to assume that South Africa wanted to take Cuito Cuanavale." 34 Of course, this is also not positive proof of the South African intentions either, but why cite only the Star report and ignore the Argus one? Because the Argus report does not fit in with a conclusion already reached? 
Suggestively he notes,

In the first months of 1988 reports in the Namibian press on the battle of Cuito Cuanavale were contradictory, but by March one thing was clear: Cuito had not fallen, despite all the predictions of South African officials that it would. In mid-April the SADF felt compelled to put out an 'information kit', to correct 'distorted perceptions' of military developments in Angola: it had never intended to seize Cuito Cuanavale, it asserted."35

In other words, Gleijeses hints that Cuito was the intended target and that the SADF was simply lying. If one can prove that, fine. But he offers no supporting material at all.

Apparently, to illustrate the enormous Cuban success, he asserts,

For over five years the United States refused to let the Cubans participate in the talks, even those dealing with the departure of the Cuban troops. But in early 1988, confronted by the evidence of growing Cuban strength in southern Angola, the Americans finally agreed to allow the Cubans to join the talks. ${ }^{36}$

While it is true that the Cubans were at last allowed to join the talks, Gleijeses offers no sources to back up his interpretation. On the contrary, he ignores Castro's message via an intermediary to Washington in late July 1987 (even before the Angolan offensive against UNITA started), suggesting that Cuba participate in talks about a political solution. Although US Assistant Secretary of State for Africa Chester Crocker took cognisance of the "guarded" tone of the message, Crocker says Castro "seemed to be saying that it would be good if the twelve-year engagement of Cuban forces in Angola ... could be concluded on honorable terms."37 Was this a diplomatic way of suing for peace?

And what about the diplomats Castro sent to the South African embassy at the United Nations in New York late in November 1987 in order (as Fred Bridgeland reports) "to explore the possibility of a negotiated settlement of the Angolan conflict", linked to "a resolution of the problem in neighbouring South African-ruled Namibia"? ${ }^{38}$ Was that the action of a man, as Gleijeses paints him, unstoppable in the march to his historically determined victory, or of a man manoeuvring very intelligently to wriggle himself out of a very difficult situation? Gleijeses ignores the growing war-weariness in Cuba, which the Cubans later admitted to General Jannie Geldenhuys, Chief of the South African Defence Force, ${ }^{39}$ as well as a message from the Cuban Deputy Minister of Foreign Affairs, Ricardo 
Alarcan, to a US diplomat that "a settlement would enable Cuba honorably to terminate a very heavy commitment". 40

Gleijeses makes much of the fact that South Africa did not strike back heavily at the Cuban reinforcements advancing southwards towards the Namibian border in May and June 1988, implying that the SADF was, at last, militarily beaten. He crows about the South African Air Force (SAAF) losing air superiority, referring to Cuban aircraft straying into Namibian air space without any reply from the SAAF. ${ }^{41}$ It is true that this advance, when viewed from a military point of view, was an excellent move and that the South Africans were understandably worried about it. Nevertheless, they kept their nerve. SA Military Intelligence did not think that the Cubans would invade Namibia - and if they did, preparations were being made to receive them very warmly. ${ }^{42}$ As a matter of fact, the SADF called up an armoured division with a dual function - to deter the Cubans in case they wanted to cross the border, and to invade Angola's Cunene Province in a large-scale operation to destroy the Cuban force there in case the negotiations failed (which, of course, they did not). ${ }^{43}$ In other words, the SADF was very far from being beaten.

Furthermore, during the period April to September 1988 the SAAF conducted photo-reconnaissance sorties of the Cuban positions at Xangongo, Humbe, Mongua and Ongiva in the hope, among other things, of luring the Cuban MiG-23s into the air. This was done after the SAAF had worked out new tactics to neutralise the MiG-23's advantages in the air, and it is fair to assume that they wanted to test these new tactics. But the Cubans did not take the bait and stayed on the ground. ${ }^{44}$ According to Gleijeses' own logic, this has to mean that the SAAF had regained air superiority. The truth is, of course, not that simple.

Gleijeses argues that Cuba's military role in Cuba was, in the end, worthwhile. He is entitled to that conclusion. But he bases it, amongst others, on the premise that "the Cuban military shield throughout the 1980s prevented the SADF from wreaking even greater destruction on the country". This follows an assertion that the positions the Cubans held on the railway between Namibe and Menongue prevented the SADF from crossing into central Angola. ${ }^{45}$ But how would the SADF have been able to do that? Supporting even one brigade near Cuito Cuanavale stressed the South African military logistics to breaking point. ${ }^{46}$

To support his basic thesis that Cuba won a glorious victory over a humiliated South Africa, Gleijeses contends that-

[o]n 22 July [1988], senior Cuban and Angolan military officers met with their South African counterparts and US officials in Cape Verde to discuss a possible cease-fire. After a few hours, the South 
Africans bowed to the Cubans' demands: they would withdraw all their troops from Angola by September 1 in exchange for an immediate cease fire. ${ }^{47}$

What Gleijeses keeps from his readers, however, is the entire process leading up to this meeting, including the remarkable Angolan and Cuban turnabout eleven days before, on 11 July, when Angolan General Antonio Dos Santos Franca and Cuban diplomat Carlos Aldana Escalante expressly gave in on linkage between the implementation of UN Resolution 435 and Cuban withdrawal from Angola, which was always contemptuously rejected by these two countries. Aldana, whose speech was written down verbatim, said at the time:

We understand that within the framework of the negotiations that we are currently holding, the question of the presence of the Cuban troops bears a relation to the implementation of Resolution 435 . Leaving aside rhetoric, we must recognise that there is a linkage. If it is not shown in this document it will be part of it, because there is a linkage. We cannot deny that fact. ${ }^{48}$

Aldana even praised South Africa for its role in the negotiations and identified himself with a sentiment expressed by that country's chief negotiator, Foreign Affairs Director-General Neil van Heerden, that no-one should come out of the process a loser; that everyone should win. ${ }^{49}$ This was only some two weeks after the combative Cuban negotiator Jorge Risquet Valdes, who almost derailed the talks, aggressively told the South Africans who demanded that Cuban troops leave Angola that they "would not get around a conference table that which it failed to achieve on the battlefield." ${ }^{50}$ It was this development, which created the space for South Africa to call it a day and to agree to leave Angola and Namibia.

Possibly Gleijeses could be on somewhat firmer ground with his conclusion that "the New York agreements would not have been possible without the Cubans' prowess on the battlefield and skill at the negotiating table". ${ }^{51}$ Tactically, this "prowess" was not thought highly of by South African officers, ${ }^{52}$ although the southward march to the Namibian border was, on the operational and military strategic level, a really excellent move. It may well be reasoned that this concentrated the South Africans' minds greatly and contributed to their willingness to engage in serious negotiations with the Cubans and Angolans.

Nevertheless, Gleijeses does not visibly contemplate the possibility of an opposite interpretation. We are, of course, now venturing onto the thin ice of informed speculation, but is it not a legitimate question to ask what would have happened if Cuba and the USSR had never intervened in Angola in 1975? It is quite 
possible that the Alvor Agreement of January 1975 (according to which the MPLA, FNLA and UNITA had to form a government of national unity and oversee elections, but fell apart because of the civil war) would have survived. It is equally possible that UNITA, possibly in alliance with the FNLA, could have taken over power, with or without South African help. In that case, it is logical to surmise that this alternative Angola (sans Cuban troops) would not have allowed SWAPO to operate from its soil, and that the South African government's feeling of being threatened and under pressure would have been much less. After all, the doctrine of "total onslaught" and "total strategy" came into being as a direct result of the Soviet/Cuban intervention in Angola. It may be reasoned that South Africa's intransigence throughout the eighties regarding the implementation of Resolution 435 was due to the perception (rightly or wrongly, that is not really relevant) of having to fight a survival struggle against "Communist imperialism".

Of course, we will never know. But at least one has to acknowledge that different scenarios might have been possible, including those which do not fit into your own ideological mould.

Perhaps Gleijeses' open admiration for Castro and Cuba and his utter revulsion at the apartheid government has something to do with all these examples. For instance, he writes, "Castro sent troops [to Angola] because he was committed to racial justice" 53 and "because of his commitment to what he [Castro] has called 'the most beautiful cause', the struggle against apartheid". ${ }^{54}$ Elsewhere, he ascribes Castro's Africa to his "revolutionary idealism. For no other country in modern times has idealism been such a key component of its foreign policy." 55 He expressly identifies himself with the sentiments by the future President Nelson Mandela when visiting Havana in 1991: "We come here with a sense of the great debt that is owed to the people of Cuba ... What other country can point to a record of greater selflessness than Cuba had displayed in its relations to Africa?"56

So be it. But there is not a single word about Castro wanting to export communism to Africa and to hurt the capitalist West, as he admitted to East German leader Erich Honecker in 1977. (Although, to be honest, he also spoke of the "liberation struggle" - presumably coupled with the socialist revolution - as "the most moral thing in existence". ${ }^{57}$ ). Neither is there anything about the irony of a communist dictator refusing to allow any political freedom in his own country whatsoever, fighting to bring "liberty" to the oppressed South African blacks ruled by an arguably less authoritarian regime. Gleijeses is also rather lenient when discussing Castro's military support for Ethiopian dictator Mengistu Haile Mariam, whose policies are recognised by him as having "resulted in disaster". $58 \mathrm{He}$ recognises the "unsavoury nature" of the Mengistu regime, but adds, "Call it bias, 
but although I cannot condemn the Cuban role, I cannot applaud it either."59 (Very little, if anything, of Marc Bloch's admonishment about the roles of the judge and the historian shows in this approach.)

It is one thing establishing the objective and undeniable fact that Castro was driven, as seen from his own perspective, by idealism. It is quite another to identify yourself so closely with Castro and his Marxist-Leninist ideology and system.

But there is more: After a research visit to South Africa in 2007, Gleijeses called Pik Botha, the National Party government's Minister of Foreign Affairs, in an interview with a Cuban newspaper "one of the most repugnant people I have ever talked to in my life". Colonel Jan Breytenbach, who commanded the parachute assault on Cassinga in May 1978, was labelled "an assassin, a war criminal". At the same time, Castro's foreign policy was one "that I admire so much". Castro himself was "the architect of such a noble work". Some people, he said, tell him his essays could be more credible "if I were to talk less favorably about Cuba". He takes this criticism seriously, he said, but then "add pages of documents strengthening my arguments". 60

No historian, including myself, is ever totally free of bias. However, a good historian will at least try to remain objective. It must, therefore, be asked: How much weight must one give to the work of one who displays his bias so unashamedly? No wonder the Cuban Council of State decorated him in 2003 with the Medal of Friendship at the initiative of the Cuban Institute of Friendship with the Peoples. ${ }^{61}$ Hopefully Gleijeses will redeem himself with his second book.

The conclusion of this overview must, therefore, be that from a strictly academic point of view none of the Cuban/Angolan apologist analyses are up to scratch.

\section{The 'serious researchers'}

A book with a wealth of information, apparently mostly gleaned from interviews with SADF field commanders, is one by the journalist Fred Bridgeland. ${ }^{62}$ Bridgeland's racy style makes this a very readable book. He emphasises the limited nature of the South African objectives, but does not try to analyse these in detail. He clearly holds no brief for either the MPLA, the Cubans or the Soviet Union, but he is also not overtly pro-South African. Nevertheless, his only sources are apparently South African or American. He has only one Cuban source, the defected Air Force General Rafael del Pino Diaz. 
This means that his book, perhaps not on purpose, has a clear South African slant in that it is chiefly the SADF story that is told, although the book never degenerates into SADF propaganda.

Another journalist who has written quite a lot about the Border War is Willem Steenkamp. Steenkamp used to be a Citizen Force officer in the SADF, and still continues as such in the SANDF. Steenkamp makes no secret of his sympathy for the SADF, but he never loses his independence. Of course, academics like Gary Baines loathe him. ${ }^{63}$ Steenkamp's book about the Border War $^{64}$ was largely based on newspaper reports and other sources he gleaned during his years as Defence Correspondent of the Cape Times. The book clearly is not intended as the definite account of the war. It is presented as a coffee-table publication with lots of colour and black-and-white photographs. At the time of publication (1990), the book filled a certain lacune, but since then, it has clearly been overtaken.

Another work to be examined is that of military writer and ex-SADF Citizen Force officer Helmoed-Römer Heitman. His comprehensive history of the final phase of the war in Angola is based on unpublished SADF archival documents and interviews with participants in the campaign. ${ }^{65}$ However, some observers clearly distrust his version of events in view of his close involvement with the SADF. ${ }^{66}$

Heitman emphasises the incremental nature of the SADF's involvement after the start of the Angolan offensive to capture the UNITA stronghold of Mavinga. The first government decision was to keep any intervention "as inconspicuous as possible". Later on, more and heavier mechanised units were sent to the battlefield. ${ }^{67}$ While FAPLA, the Angola Army, was being trounced at the Lomba, President PW Botha, accompanied by several generals, visited Mavinga (28-29 September 1987) and ordered that a counteroffensive be launched to crush the FAPLA forces so completely that they would be unable to begin another offensive before the end of 1988.

Once again, based on archival documents, Heitman reports that an attack on Cuito Cuanavale was considered at the end of November 1987, but ruled out. He quotes Lieutenant-General "Kat" Liebenberg, Chief of the Army, that it would have left South Africa in the position of "the dog that finally has caught the bus". His assessment goes on:

If the South Africans were to actually occupy Cuito Cuanavale, they would have to accept either the political damage of holding on to a town in Angola, or the propaganda damage of their withdrawal being turned into a great Fapla victory. If they were to stop their operation short of actually taking the town, they would again be handing 
Angola propaganda ammunition. Militarily perhaps the most logical option, a south-western approach [to take the town] was seen as too likely to bring with it political problems outweighing the military advantages. This option was therefore again ruled out. ${ }^{68}$

Once again basing it on a document, Heitman confirms that one of the guidelines issued for Operation Hooper was that "Cuito Cuanavale might be taken if the opportunity arose to do so relatively easily". ${ }^{9}$

Heitman does not question the rights and wrongs of the war. He is above all a military technocrat who tries to reconstruct events as faithfully as possible. He, too, had no access to any non-South African sources. He did have full access to the documents in the SADF Documentation Centre, and also spoke to eyewitnesses in the SADF. As such, although his research was comprehensive, his book is primarily a look through the SADF's eyes, and it lacks Cuban, Angolan and Soviet perspectives. Considering the time of publication (1990) it could not be otherwise. If one takes this limitation into account, Heitman's is a very workmanlike and accurate book for the SADF perspective.

Another work warranting our attention is an MA thesis in Strategic Studies by Andreas Velthuizen, which was completed in 1991. Velthuizen, a professional ex-SADF officer, had free access to the SADF archives, but was not able to consult any Cuban, Angolan or Soviet sources. As such, his work has a SADF perspective in common with the previous three, the difference being that it is an academic study with proper references and having gone through the proper stringent evaluation for graduation purposes. With this limitation in mind, Velthuizen has also written an accurate account from which the limited SADF objectives (including the fact that the South Africans never intended to take Cuito Cuanavale) is apparent. ${ }^{70}$ While admitting that "the Cuban presence on the Namibian border in 1988" meant that "for the first time South Africa had a military disadvantage with the much feared threat of a conventional war in Namibia becoming a possibility", and that this "was to have a decisive influence on negotiations for peace in Angola and independence for Namibia", his basic conclusion is:

Although ideal security conditions could not be created, the South African government demonstrated its will and capabilities to escalate military intervention in a crisis situation. This ensured a new urgency to find a political settlement in which the presence of Cuban forces in Angola and the independence of Namibia were linked. The South African government could negotiate with its adversaries from a position 
of strength in the belief that the SADF, despite military setbacks and the exploitation of these for propaganda purposes, could still be used as an instrument by the South African government if the need existed. ${ }^{71}$

From this follows a conclusion that the Cuban withdrawal meant that -

... the balance of conventional military power in Africa shifted and the SADF no longer faced any credible threat. South African rulers could look at their strategic and political position as strengthened, despite the 'loss' of Namibia. Conventional military power became less relevant and it was proved that South African interests could be advanced through negotiations. ${ }^{72}$

Velthuizen has since followed this up with an academic article in which he backtracks to a certain extent and moves a certain distance towards the opposite camp. $^{73}$

Finally, we have to consider the work by Professor Christopher Saunders, historian at UCT. Saunders has done extensive research in the archives of the Department of Foreign Affairs and was responsible for the publication of a selection of the most important documents on the internet. With this, he has done historical writing an enormous service. ${ }^{74}$ Although he apparently has done no research in the Documentation Centre of the SANDF, he is well informed on the secondary literature about the Border War. ${ }^{75}$ Saunders, too, apparently had little love for the National Party government, but kept his dislike within acceptable boundaries. His conclusion is that "the military stalemate in southern Angola by early 1988" is one of the reasons for the final outcome. ${ }^{76}$ Beyond that, he has concentrated very ably on the diplomatic happenings behind the scenes. ${ }^{77}$

\section{Conclusion}

Earlier in this article, we saw how difficult the question of objectivity and impartiality is. It begins with the problems of piecing together the events of the past, where the historian inevitably selects which facts to include, from which angle to view them, and according to which paradigm to interpret them. It is, therefore, selfevident that differing and opposing interpretations of the past will be the order of the day, and that personal beliefs will play a role.

To counter this, the modern historian has at his disposal a battery of intellectual instruments, as set out in many handbooks about the art (some prefer science) of historical writing. Even so, differences will remain. 
The problem is that some historians are so consumed by their own worldview that it edges out the intellectual apparatus referred to above. The result is that they adapt the facts to their paradigm, instead of being led by the facts.

I am afraid that the "anti-SADF" researchers whose work was discussed above, have all crossed the line to a lesser or greater extent. This is a pity, because especially Professors Baines and Gleijeses have otherwise done some very valuable work indeed.

Let me be as clear as I possibly can about this: I am not critical of the "nonresearchers" because they are sympathetic towards Cuba and unsympathetic towards the National Party government in South Africa. No democrat will ever deny them that right. I am looking at them from an academic point of view. And judged by this standard, the harsh fact is that they fall short.

Unfortunately, most of them resort to (Cuban) propaganda instead of serious academic work. Undoubtedly, the National Party government also resorted to similar propaganda at the time. But I am not aware of any serious academic regurgitating National Party propaganda about the Border War in the same way as the "nonresearchers" do.

The "serious research" viewpoint has not been taken up by academics to any measurable extent, at least not as far as the military aspects of the war is concerned. It would seem that I am rather isolated, at any rate among academics. That is fine. The "non-research" school is welcome to stay with their views; we cannot always agree on everything. I simply hope that their conclusions will in future be built on more solid academic grounds. At present, they are not.

${ }^{1}$ Dr Leopold Scholtz is at present the Media24 correspondent in Europe. He has also completed several terms as Professor Extraordinaire in the Department of History, Stellenbosch University, and continues as research fellow in the same department. He has served in both the Citizen Force of the SADF (1966-'75) and the Reserve Force of the SANDF (1997-present).

${ }^{2}$ Vide Scholtz, L. "Cuito Cuanavale: Wie het regtig gewen?" Scientia Militaria 28/1. 1998; Scholtz, L. “'n Strategiese en operasionele beoordeling van die Suid-Afrikaanse Weermag (SAW) se oorgrens-operasies in Angola, 19781988”. Joernaal vir Eietydse Geskiedenis 33/3. December 2008; Scholtz, L. "The South African strategic and operational objectives in Angola 1987'88'. Scientia Militaria 38/1. 2010.

${ }^{3}$ Van Jaarsveld, FA. Moderne geskiedskrywing. Durban: Butterworth, 1982, 74.

${ }^{4}$ Marwick, A. The nature of history. $2^{\text {nd }}$ ed. London: Macmillan, 1981, p. 21.

${ }^{5}$ Carr, EH. What is history? London: Penguin, 1964, 29-30.

${ }^{6}$ Groot, G. Inleiding tot de geschiedenis. Utrecht: Ambo, 1968, 48-49. 
${ }^{7}$ Scholtz, GD. Die taak van die historikus. Johannesburg: Publications of the RAU A27, 1970, 15-16. ("A historian which becomes victim of his own subjective feelings when he takes up the pen, is not a historian in the true sense of the word ... One of the most important tests for the greatness of a historian is the way in which he is prepared to advance a truth which may be unpleasant for his own feelings and opinions and to put it in the right perspective.")

${ }^{8}$ Bloch, M. The historian's craft. New York: Alfred A. Knopf, 1953, 138-153.

${ }^{9}$ Saney, I. "African Stalingrad: The Cuban revolution, internationalism and the end of apartheid". Latin American Perspectives 33/81. 2006. 101.

${ }^{10}$ Campbell, H. "The military defeat of the South Africans in Angola". Montly Review. April 1989. 1-15.

${ }^{11}$ Cf. Ex-Combatant Association (ECA): Freedom trail. <www.mozguide.com/angola/images/ECA-FreedomTrail.pdf> Accessed on 11.2.2009.

${ }^{12}$ Saney, I. Cuba: A revolution in motion. Halifax: Fernwood, 2004.

${ }^{13}$ Campbell, op. cit. p. 2.

${ }^{14}$ Scholtz, L. "The air war over Angola, 1987-'88: An analysis". Journal for Contemporary History. 33/3. December 2008.

${ }^{15}$ Vide Scholtz, "The South African strategic and operational objectives ...", op. cit.

${ }^{16}$ Baines, G. "Challenging the boundaries, breaking the silences". In Baines, G \& Vale, P (eds.), Beyond the Border War: New perspectives on Southern Africa's late-Cold War conflicts, Pretoria: Unisa, 2008, 4.

${ }^{17}$ Baines, G. Breaking rank: Secrets, silences and stories of South Africa's Border War. <www.inter-disciplinary.net/ptb/wvw/wvw4/baines\%20paper.pdf> Accessed on 7.8.2009.

${ }^{18}$ Holt, C. At thy call we did not falter: A frontline account of the 1988 Angolan War, as seen through the eyes of a conscripted soldier. Cape Town: Zebra, 2004.

${ }^{19}$ Behr, M. The smell of apples. London: Abacus, 1998.

${ }^{20}$ Baines, G. Trauma in transition: Representing psychological problems of South African war veterans.

<wwwmcc.murdoch.edu.au/trauma/docs/baines_g.pdf > Accessed on 9.10.2010.

${ }^{21}$ Scholtz, "The South African strategic and operational objectives ...", op. cit.

22 Dosman, EJ. "Countdown to Cuito Cuanavale: Cuba's Angolan campaign". In Baines, G \& Vale, P (eds.), Beyond the Border War: New perspectives on Southern Africa's late-Cold War conflicts, Pretoria: Unisa, 2008, 211.

${ }^{23}$ Ibid. p. 227.

24 The South African Military History Society. Newsletter - June 2007. <rapidttp.co.za/milhist/7/07junnl.html> Accessed on 7.9.2008.

${ }^{25}$ Heitman, H-R. War in Africa. Gibraltar: Ashanti, 1990, ch. 34; Bridgeland, F. The war for Africa: Twelve months that transformed a continent. Gibraltar: Ashanti, 1990, ch. 38. 
${ }^{26}$ Cf. Lord, D. From fledgeling to eagle: The South African Air Force during the Border War. Johannesburg: 30 Degrees South Publishers, 2008, 449-450. Cf. also Velthuizen, A. "Applying military force for political ends: The case of South Africa in Southwestern Africa, 1987-1988”. Unpublished MA thesis, Unisa, 1991, 107.

${ }^{27}$ Blanch, HL \& Liebenberg, I. “A view from Cuba: Internationalists against apartheid”. Journal for Contemporary History 34/1. February 2009. 83.

${ }^{28}$ Gleijeses, P. Conflicting missions: Havana, Washington, Pretoria. Alberton: Galago, 2003.

${ }^{29}$ Gleijeses, P. "Moscow's proxy? Cuba and Africa 1975-1988”. Journal of Cold War Studies 8/2. Spring 2006. 37; Gleijeses, P. "Conflicting versions: Cuba, the United States and Angola”. In Franco, M (ed), Portugal, os Estados Unidos e a África Austral, Lisbon: Instituto Portugués das Relaçoes Internacionais, 2006, 119-35; Gleijeses, P. "Cuba and the independence of Namibia". Cold War History 7/2. May 2007; Gleijeses, P. The Cuban drumbeat. Castro's worldview: Cuban foreign policy in a hostile world. London: Seagull, 2009; Gleijeses, P. "Cuito Cuanavale revisited". Mail \& Guardian 6-12.7.2007.

${ }^{30}$ Gleijeses, "Moscow's proxy?", op. cit. p. 26.

${ }^{31}$ Gleijeses, "Moscow's proxy?", op. cit. p. 37.

${ }^{32}$ Scholtz, "The South African strategic and operational objectives ...", op. cit. pp. 76-77.

${ }^{33}$ Gleijeses, "Moscow's proxy?", op. cit. p. 292.

${ }^{34}$ Cf. Santa Rita, J. "SA's long guns put pressure on Angolans". The Argus. 20 February 1988.

${ }^{35}$ Gleijeses, "Cuba and the independence of Namibia", op. cit. p. 294.

${ }^{36}$ Gleijeses, "Cuba and the independence of Namibia", op. cit. p. 294.

${ }^{37}$ Crocker, C. High noon in Southern Africa: Making peace in a rough neighborhood. Johannesburg: Jonathan Ball, 1992, 355.

${ }^{38}$ Bridgeland, op. cit. p. 228. Cf also Geldenhuys, J. Dié wat gewen het: Feite en fabels van die Bosoorlog. Pretoria: Litera, 2007, 191.

${ }^{39}$ Geldenhuys, op. cit. p. 183.

${ }^{40}$ Crocker, op. cit. p. 362.

${ }^{41}$ Gleijeses, "Cuba and the independence of Namibia", op. cit. pp. 295-296.

${ }^{42}$ Cf. Scholtz, "The South African strategic and operational objectives ...", op. cit. pp. 92-93; Geldenhuys, op. cit. p. 191-192.

${ }^{43}$ Velthuizen, op. cit. A. "Applying military force for political ends: The case of South Africa in Southwestern Africa, 1987-1988". Unpublished MA thesis, Unisa, 1991, 107; Lord, op. cit. pp. 449-450.

${ }^{44}$ Geldenhuys, op. cit. p. 199.

${ }^{45}$ Gleijeses, "Moscow's proxy?", op. cit. p. 27.

${ }^{46}$ Cf. Scholtz, "The air war over Angola ...", op. cit. p. 257.

${ }^{47}$ Gleijeses, "Conflicting versions", op. cit. p. 132. 
${ }^{48}$ Aluka. Minutes of a meeting between reprentatives from South Africa, Angola, Cuba and the USA. 11 July 1988. 10.

$<$ www.aluka.org/action/doBrowse?sa=hist\&t=2067\&br=taxcollections\%

7Cpart-of\%7Ccollection-minor> Accessed on 3.2.2009.

49 Ibid.

${ }^{50}$ Aluka. Minutes of a meeting between delegations from South Africa, Angola, Cuba and the US in Cairo. 24-25 June 1988. 7.

$<$ www.aluka.org/action/doBrowse?sa=hist\&t=2067\&br=taxcollections\%7C part-of\% 7Ccollection-minor $>$ Accessed on 3.2.2009.

${ }^{51}$ Gleijeses, "Cuba and the independence of Namibia", op. cit. p. 297.

${ }^{52}$ Cf. Geldenhuys, op. cit. pp. 197-199; Breytenbach, J. Buffalo Soldiers: The story of South Africa's 32 Battalion. Alberton: Galago, 2002, 322-344; Scholtz,

"The South African strategic and operational objectives ...", op. cit. p. 93.

${ }^{53}$ Gleijeses, "Conflicting versions", op. cit. pp. 123-124.

${ }^{54}$ Gleijeses, The Cuban Drumbeat, op. cit. p. 30.

55 Gleijeses, "Moscow's proxy?", op. cit. p. 49.

${ }^{56}$ Gleijeses, "Moscow's proxy?", op. cit. p. 51.

${ }^{57}$ Author. Fidel Castro's 1977 Southern Africa tour: A report to Honecker. 3 April 1977. <http://macua.blogs.com/files/castro-in-africa.doc> Accessed on 2.8.2006. ("The liberation struggle in Africa has a great future. From a historical perspective the facts are that the imperialists cannot turn things back. The liberation struggle is the most moral thing in existence. If the socialist states take the right positions, they could gain a lot of influence. Here is where we can strike heavy blows against the imperialists.") Cf. also Gleijeses, "Moscow's proxy?", op. cit. pp. 13-14.

${ }^{58}$ Gleijeses, The Cuban Drumbeat, op. cit. pp. 38-39.

${ }^{59}$ Gleijeses, "Moscow's proxy?", op. cit. pp. 49-50.

${ }^{60}$ Blanch, HL. "Professor Piero Gleijeses of John Hopkins University: 'Cuba is a pearl in the history of Africa"”. Juventud Rebelde. 28 March 2008. <www.juventudrebelde.co.cu/cuba/2008-03-28/cuba-is-a-pearl-in-thehistory-of-africa> Accessed on 3.7.2009.

${ }^{61}$ Minuti, G. "Piero Gleijeses: A truly special Italian". Granma. 19 August 2004. <http://www.latinamericanstudies.org/cuba/piero.htm> Accessed on 3.7.2009.

${ }^{62}$ Bridgeland, op. cit.

${ }^{63}$ Baines, B. The Battle for Cassinga: Conflicting narratives and contested meanings. <http://eprints.ru.ac.za/946/1/baines_Cassinga.pdf> Accessed on 8.8.2010; Baines, B. "Partial sources colour the Cassinga story". Sunday Independent. 17 February 2008.

${ }^{64}$ Steenkamp, W. South Africa's Border War. Gibraltar: Ashanti, 1990.

${ }^{65}$ Heitman reports in a personal communication (24 December 2009) "that I was given access to all of the files, but on the condition that I took nothing with me and made no specific reference to any document ... That said, where I 
quote someone, it was from a personal interview, and where I quote from orders or signals, it was from the original document".

${ }^{66}$ Cf. Minter, W. "War in Angola: The final South African phase". Africa Today 39/1-2. Winter-Spring 1992. 130-135.

${ }^{67}$ Heitman, H-R. War in Angola: The final South African phase. Gibraltar: Ashanti, 1990, passim.

${ }^{68}$ Ibid., p. 169.

${ }^{69}$ Ibid., p. 179. (Heitman's emphasis.)

${ }^{70}$ Velthuizen, op. cit. pp. 96-97.

${ }^{71}$ Velthuizen, op. cit. pp. 119; 121.

${ }^{72}$ Ibid. p. 112.

${ }^{73}$ Velthuizen, A. "The significance of the Battle for Cuito Cuanavale: Long-term foresight of the current strategic landscape". Scientia Militaria 37/2. 2009.

${ }^{74}$ Saunders, C. South Africa Department of Foreign Affairs: Regional negotiations, 1976-1986. <http://ts-den.aluka.org.ez.sun.ac.za/delivery/alukacontentdelivery/pdf/10.5555/AL.SFF.DOCUMENT.ae000130?type=txt\&q=1 ow\&doi=10.5555\%2FAL.SFF.DOCUMENT.ae000130\&url=http\%3A\%2F $\% 2$ Fwww.aluka.org\&path $=\% 2$ Fpublisher $\% 2$ Faluka $\% 2$ Fjournals $\% 2$ Fproduct ion $\% 2 \mathrm{Fsff} \% 2 \mathrm{Faluka} \% 2 \mathrm{Fcollection}$. saofa\%2Fphase_01\%2F01\%2F01\%2F10 $.5555 \% 252$ fal.sff.document.ae $000130 \% 2 \mathrm{~F} 10.5555 \% 252 \mathrm{fal}$. sff.document.ae 000130.prime_v01> Accessed on 3.7.2008.

75 Saunders, C. "The history and historiography of Namibian decolonisation". South African Historical Journal 9/31. November 1994. 221-234.

${ }^{76}$ Saunders, C. "The United States and Namibian independence, c. 1975-1989". South African Historical Journal 28/1. June 2003. 91.

${ }^{77}$ Cf. Saunders, C. The South Africa-Angolan talks: A little-known Cold War thread. <http://www2.1se.ac.uk/IDEAS/programmes/africaProgramme/events/confer ences/Southern $\% 20$ Africa\%20in\%20the $\% 20$ Cold $\% 20$ War $\% 20$ $\% 20$ May\%2009/pdfs/papers/Saunders.pdf> Accessed on 3.7.2008. 